\title{
Starvation recovery of Staphylococcus aureus 8325-4
}

\author{
Mark O. Clements and Simon J. Foster
}

Department of Molecular Biology and Biotechnology, University of Sheffield, Firth Court, Western Bank, Sheffield S10 2TN, UK
Author for correspondence: Simon J. Foster. Tel: +44114 222 4411. Fax: +44 1142728697. e-mail: s.foster@sheffield.ac.uk

\begin{abstract}
Nutrient limitation of Staphylococcus aureus induces a starvation-survival state which enables it to survive until sufficient nutrients become available to support growth. The response of starved S. aureus cells to nutritional upshift was analysed to characterize the recovery mechanism which results in the resumption of rapid growth. S. aureus 8325-4 starved for $7 \mathrm{~d}$ in a chemically defined medium limited for glucose was able to resume growth upon the addition of complex medium (brain heart infusion broth) or a mixture of amino acids and glucose. The addition of either glucose or amino acids alone did not lead to recovery of cells. Prior to the first cell division event, a lag period of about 120-150 min was observed, the duration of which was independent of the length of starvation survival. During this lag period, RNA synthesis increased immediately upon the addition of nutrients whilst protein synthesis was delayed by approximately 5 min. Cells rapidly enlarged within $30 \mathrm{~min}$ of recovery, and initiation of chromosome replication could be detected after $90 \mathrm{~min}$. Changes in the profile of proteins expressed during the recovery period revealed that several starvation-specific proteins were downregulated within $30 \mathrm{~min}$, whilst other proteins were common to both starvation and recovery. Two proteins were identified which were only transiently expressed during the first 60 min of recovery. Protein synthesis could be detected during recovery even if the cells had been treated with the RNA synthesis inhibitor rifampicin for $\mathbf{3 0}$ min prior to the addition of recovery nutrients, demonstrating that several proteins are translated from long-lived mRNA transcripts present in starved cells.
\end{abstract}

Keywords: recovery, starvation, Staphylococcus aureus, long-lived mRNA, recoveryspecific proteins

\section{INTRODUCTION}

Many bacteria in the natural environment, where nutrient deprivation may be common, lead a feastfamine existence. To survive long periods of nutrient deprivation many non-spore-forming bacteria have developed specific starvation-survival responses which enable the bacteria to persist in the environment in a reduced metabolic state. To compete with other microorganisms, once nutrients become available the surviving cells must have an alert sensory mechanism enabling rapid recovery from the starved state, thus allowing ensuing growth.

Abbreviations: BHI, brain heart infusion broth; CDM, chemically defined medium.
The starvation-survival responses of Escherichia coli, Salmonella typhimurium, Pseudomonas putida, Micrococcus luteus and several marine Vibrio species have been well characterized (Givskov et al., 1994a; Kjelleberg et al., 1993; Kolter et al., 1993; Mukamolova et al., 1995; Spector \& Cubitt, 1992). In general, nutrient starvation leads to reductive cell division giving rise to smaller cells, often more spherical, with increased stressresistance properties. Analysis of cellular proteins synthesized during starvation by two-dimensional SDSPAGE has shown that differential protein synthesis occurs, with proteins expressed in a specific temporal order (Givskov et al., 1994b; Nystrom et al., 1991; Spector et al., 1986). Several genes required for the development of the starvation-survival state have been identified including an alternative sigma factor $r p o S$, bolA involved in morphological changes, and catalases 
involved in oxidative stress resistance (Aldea et al., 1988; Hengge-Aronis, 1996; Mulvey et al., 1990).

Starvation of some bacteria, including several pathogenic Vibrio species, apparently leads to the development of a 'viable but non-culturable' (VBNC) state characterized by the formation of cells which demonstrate metabolic activity but can not resume growth upon addition of nutrients (Oliver, 1993; Xu et al., 1982). However, the existence of the VBNC state is open to some debate. $M$. luteus, upon starvation, seems to enter a state of dormancy and can only be recovered by the addition of a recovery pheromone (Kaprelyants $e t$ al., 1994).

Staphylococcus aureus is a major human pathogen capable of causing a wide range of infections. The persistence of $S$. aureus in the hospital environment is a contributing factor to the development of sometimes fatal post-operative infections (Kloos \& Bannerman, 1994). For $S$. aureus to persist under such nutrientlimiting conditions, it must be capable of long-term starvation survival. We have recently characterized the starvation-survival response of $S$. aureus (Watson et al., 1998). Starvation for carbon or multiple nutrients led to about $0 \cdot 1 \%$ of the population developing a long-term survival potential. The cells became smaller and more electron dense, and developed increased stress-resistance properties. These properties were dependent on proteins synthesized during the transition into the starved state. Therefore $S$. aureus has a starvation-survival response analogous to that of E. coli and S. typhimurium, and does not apparently enter a VBNC state.

For starved cells to resume vegetative growth they must be able to recover from starvation. Little is known about the mechanism by which starved cells respond to the availability of fresh nutrients and resume active growth. Recovery can be defined as the lag period before cell division occurs, during which time the cell reverses many of the changes that have occurred during starvation. Analysis of proteins synthesized during this recovery period in E. coli, P. putida and Vibrio sp. S14, has shown that proteins specific for starvation survival are rapidly down-regulated, whilst new proteins required for resumption of growth are up-regulated (Albertson et al., 1990b ; Givskov et al., 1994b; Siegele \& Guynn, 1996). Some of the proteins synthesized during this period appear to be unique to recovery and are only transiently expressed. In Vibrio sp. S14, several of these recovery-specific proteins are encoded by extremely stable mRNA molecules which are synthesized during starvation survival, but are only translated upon addition of nutrients to the starved cell (Albertson et al., 1990a). Presumably these proteins are essential for the early events during recovery.

This paper describes the characterization of the recovery process in $S$. aureus and analysis of the physiological and biochemical events occurring during the recovery from the starved state.

\section{METHODS}

Growth, starvation and recovery of starved cells. $S$. aureus 8325-4 (Novick, 1967) was grown in a chemically defined medium (CDM) (Hussain et al., 1991), containing 0.1\% glucose, which was glucose-limiting upon the entry to the stationary phase of growth (Watson et al., 1998). Starvation cultures were prepared by inoculation of $C D M$ to $\mathrm{OD}_{600} 0.01$ (Jenway 6100 spectrophotometer), which was then incubated at $37^{\circ} \mathrm{C}$ with shaking ( 250 r.p.m.). Stationary phase was reached after about $8-10 \mathrm{~h}$ incubation $\left(1-5 \times 10^{8}\right.$ c.f.u. $\left.\mathrm{ml}^{-1}\right)$. After $18 \mathrm{~h}$, cultures were transferred to static incubation for a further $7 \mathrm{~d}$ at $37^{\circ} \mathrm{C}$. Starved cells were recovered by the addition of 0.1 vol. glucose $(1 \%, \mathrm{w} / \mathrm{v})$ and a mixture of 18 amino acids $\left(29.4 \mathrm{mg} \mathrm{m}^{-1}\right)$ or a $0 \cdot 1$ vol. brain heart infusion broth (BHI; final concn $37 \mathrm{~g} \mathrm{l}^{-1}$ ). This gives a final added concentration of glucose and amino acids identical to the original CDM in which the cells were grown. Cultures were incubated at $37^{\circ} \mathrm{C}$ with shaking (250 r.p.m.) during the recovery period. All graphs presented in this paper are representative of the results obtained from at least three independent experiments which showed no more than tenfold variability between equivalent time points.

$\left[{ }^{3} \mathrm{H}\right]$ Uridine and $\left[{ }^{3} \mathrm{H}\right]$ methionine incorporation. Cells were starved in methionine-free CDM for $7 \mathrm{~d}$. Cultures $(5 \mathrm{ml})$ were incubated at $37^{\circ} \mathrm{C}$ with shaking (250 r.p.m.) for 60 min prior to the initiation of recovery; $30 \mathrm{~min}$ prior to recovery either [5$\left.{ }^{3} \mathrm{H}\right]$ uridine (4.66 TBq mmol ${ }^{-1}$; Amersham) or $\mathrm{L}-\left[\right.$ methyl $\left.{ }^{3} \mathrm{H}\right]$ methionine (3.07 TBq mmol ${ }^{-1}$; Amersham) was added to a final concentration of $49 \mathrm{nM}$ or $34 \mathrm{nM}$, respectively. Recovery was initiated by the addition of 0.1 vol. glucose $(1 \%, \mathrm{w} / \mathrm{v})$ and a mixture of 18 amino acids (methionine-free; $28.0 \mathrm{mg} \mathrm{ml}^{-1}$ ). At intervals, $50 \mu \mathrm{l}$ aliquots were removed into $50 \mu \mathrm{l}$ ice-cold lysis buffer [ $10 \mathrm{mM}$ Tris/HCl, $\mathrm{pH} 7 \cdot 4,10 \mathrm{mM}$ EDTA, $0.5 \mathrm{mg}$ $\mathrm{ml}^{-1}$ lysostaphin (Sigma), $1 \mathrm{mM}$ PMSF] containing either $10 \mathrm{mM}$ unlabelled uridine or methionine. The sample was repeatedly freeze-thawed (5-10 times) in dry ice/ethanol until lysis was visible by light microscopy. Trichloroacetic acid $(1 \mathrm{ml} ; 3 \%, \mathrm{w} / \mathrm{v})$ was added and the samples filtered through a $0.2 \mu \mathrm{m}$ polycarbonate filter (Whatman Cyclopore) and the filter rinsed twice with $4 \mathrm{ml}$ trichloroacetic acid. The filter was added to $5 \mathrm{ml}$ scintillation fluid (Safefluor-S) and the incorporation determined using a Beckman LS1801 scintillation counter.

Electron microscopy. Samples for examination were pelleted $\left(10000 \mathrm{~g}\right.$ for $5 \mathrm{~min}$ at $4{ }^{\circ} \mathrm{C}$ ) and the supernatant removed. Standard fixing and staining (uranyl acetate and Reynolds lead citrate) techniques were used to prepare cell sections which were examined using a Philips CM-10 electron microscope. Observations were determined from an average of 50 cells.

Flow-cytometric determination of chromosome replication. Rifampicin $\left(330 \mu \mathrm{g} \mathrm{ml}^{-1}\right)$ was added to $1 \mathrm{ml}$ cells during recovery to inhibit initiation of chromosome replication. Samples were incubated for $1 \mathrm{~h}$ to allow completion of existing rounds of replication (Ảkerlund et al., 1995). DNA content of the cells was determined by the method of Diaper \& Edwards (1994).

Analysis of protein synthesis during recovery. Samples during recovery and starvation were pulse-labelled with $\left[{ }^{35} \mathrm{~S}\right]$ methionine, the proteins separated by $10 \%(\mathrm{w} / \mathrm{v})$ SDSPAGE, and the labelled proteins visualized by fluorography, as described by Watson et al. (1998). 


\section{RESULTS}

\section{Induction of recovery}

The ability of $S$. aureus $8325-4$ cells to recover from starvation in response to different nutrients was investigated. Cells were grown in glucose-limiting CDM prior to incubation for $7 \mathrm{~d}$ at $37^{\circ} \mathrm{C}$. After this period a stable population of surviving cells (about $1 \times 10^{6}$ c.f.u. $\mathrm{ml}^{-1}$ ) corresponding to $0.1 \%$ of the initial population (upon entry to stationary phase) was maintained (Watson et al., 1998). Recovery of starved cells was determined by measuring an increase in c.f.u. $\mathrm{ml}^{-1}$ after the addition of recovery nutrients to the cell culture (Fig. 1). The

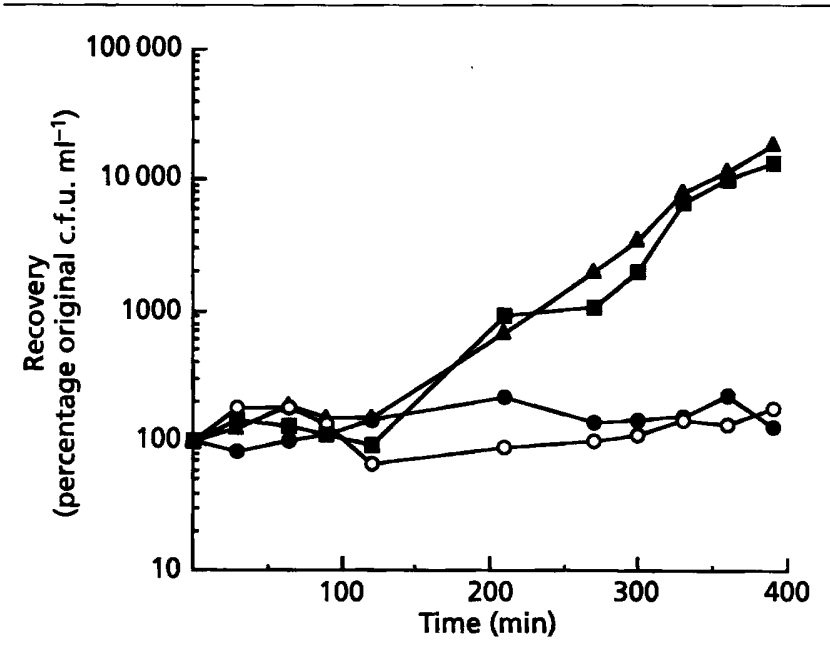

Fig. 1. Effect of nutrients on the recovery of starved cells. Nutrients were added to cultures of starved cells at the concentrations stated in Methods and the change in viable cell numbers was monitored by agar plate counts. $\mathbf{A}, \mathrm{BHI}$; glucose; $O$, amino acids; $\mathbf{\square}$, glucose + amino acids.

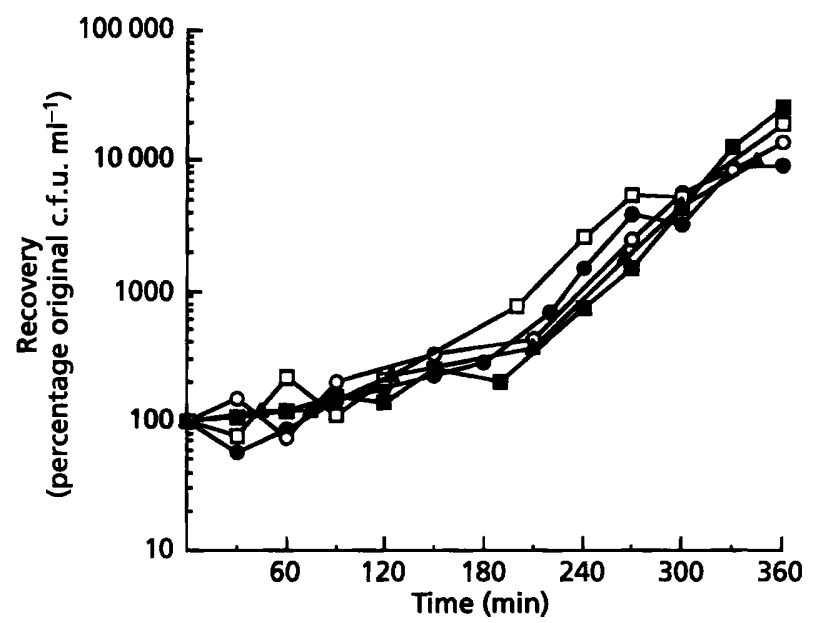

Fig. 2. Effect of the duration of starvation on the recovery lag period. Glucose and amino acids were added to starved cells to induce recovery, which was monitored by changes in c.f.u. $\mathrm{ml}^{-1}$. Cells were recovered after $2 \mathrm{~d}(0), 4 \mathrm{~d}(0), 9 \mathrm{~d}(\square), 13 \mathrm{~d}(\square)$, $26 \mathrm{~d}(\Lambda)$
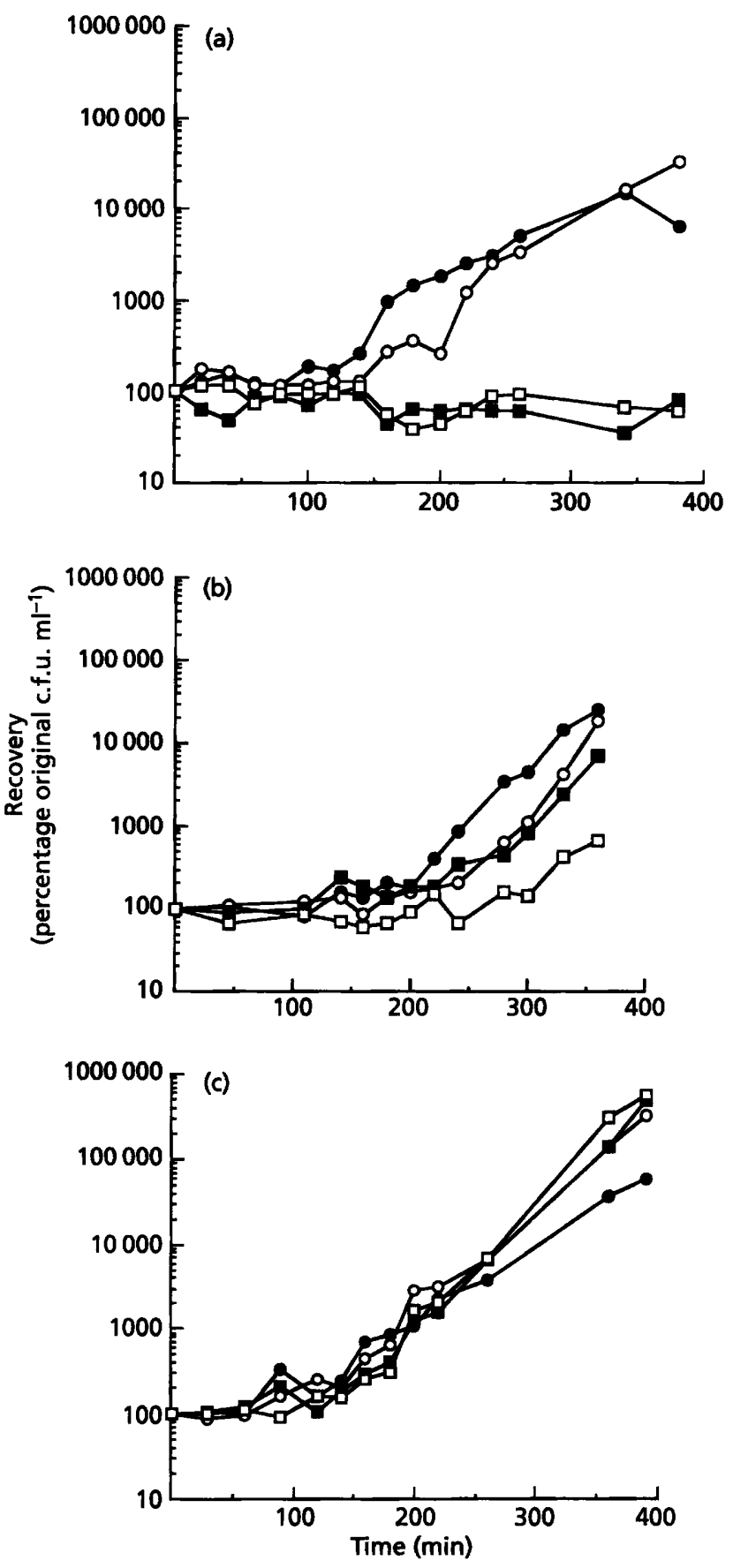

Fig. 3. Effect of cell density and conditioned culture fluid on recovery. Starved cells were harvested, washed in PBS and resuspended at different cell densities in either (a) CDM, (b) spent starved culture supernatant supplemented with glucose and amino acids, or (c) BHI. Cell densities (c.f.u. $\mathrm{ml}^{-1}$ ) were as follows: $0,1 \times 10^{6} ; 0,1 \times 10^{5} ; \square, 1 \times 10^{4} ; \square, 1 \times 10^{3}$. Recovery was measured by monitoring changes in c.f.u. $\mathrm{ml}^{-1}$.

addition of complex medium (BHI) or a mixture of glucose and amino acids led to recovery of the cells, with an increase in cells numbers after a lag period of about 120-150 min. The addition of either glucose or amino acids alone was not sufficient to enable cells to grow and 

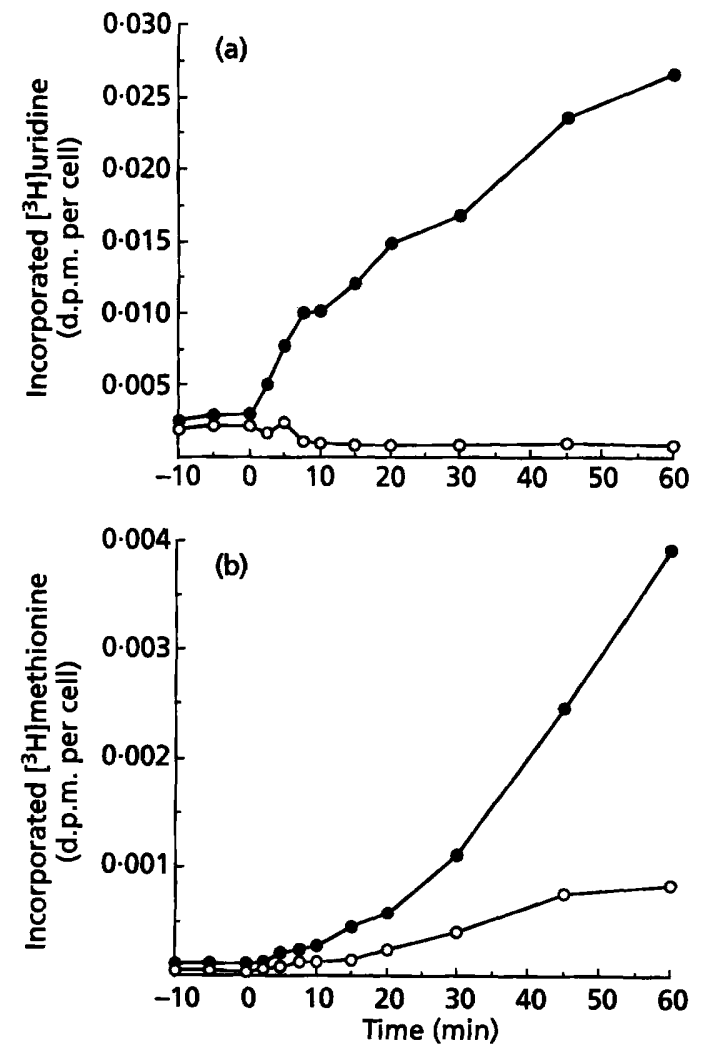

Fig. 4. Changes in the rate of RNA and protein synthesis during recovery. Incorporation of (a) $\left[{ }^{3} \mathrm{H}\right]$ uridine and (b) $\left[{ }^{3} \mathrm{H}\right]$ methionine was measured in the absence and presence of rifampicin $\left(330 \mu \mathrm{g} \mathrm{ml}^{-1}\right)$, which was added to the cells simultaneously with the recovery nutrients to inhibit RNA synthesis. Cells were incubated with the labelled isotopes for 30 min prior to addition of glucose and amino acids to initiate recovery (time 0 ). Incorporation of labelled isotope in the absence of rifampicin; $O$, incorporation in the presence of rifampicin.

divide (Fig. 1). The inability to resume growth when glucose is added to starved $S$. aureus cells is presumably due to the complex amino acid requirements for growth in defined media (Hussain et al., 1991). No difference was observed in the c.f.u. $\mathrm{ml}^{-1}$ when cells were plated on either BHI or CDM. Unlike Vibrio sp. S14 (Albertson et al., 1990b), the duration of the lag period before the first round of cell division was independent of the length of starvation, recovery having comparable kinetics whether the cells had been starved for any period between 2 and $26 \mathrm{~d}$ (Fig. 2). Since the addition of glucose and amino acids gave a reproducible recovery response, this was chosen as the standard recovery condition during the rest of the study.

The effect of cell density and factors present in the starved-conditioned culture fluid on the rate of recovery were analysed. When cells were removed from the culture fluid in which they were starved, washed and then diluted into fresh CDM, recovery was found to be density dependent (Fig. 3a). At cell densities of $1 \times 10^{5}$ or greater, the cells recovered after a typical lag period of
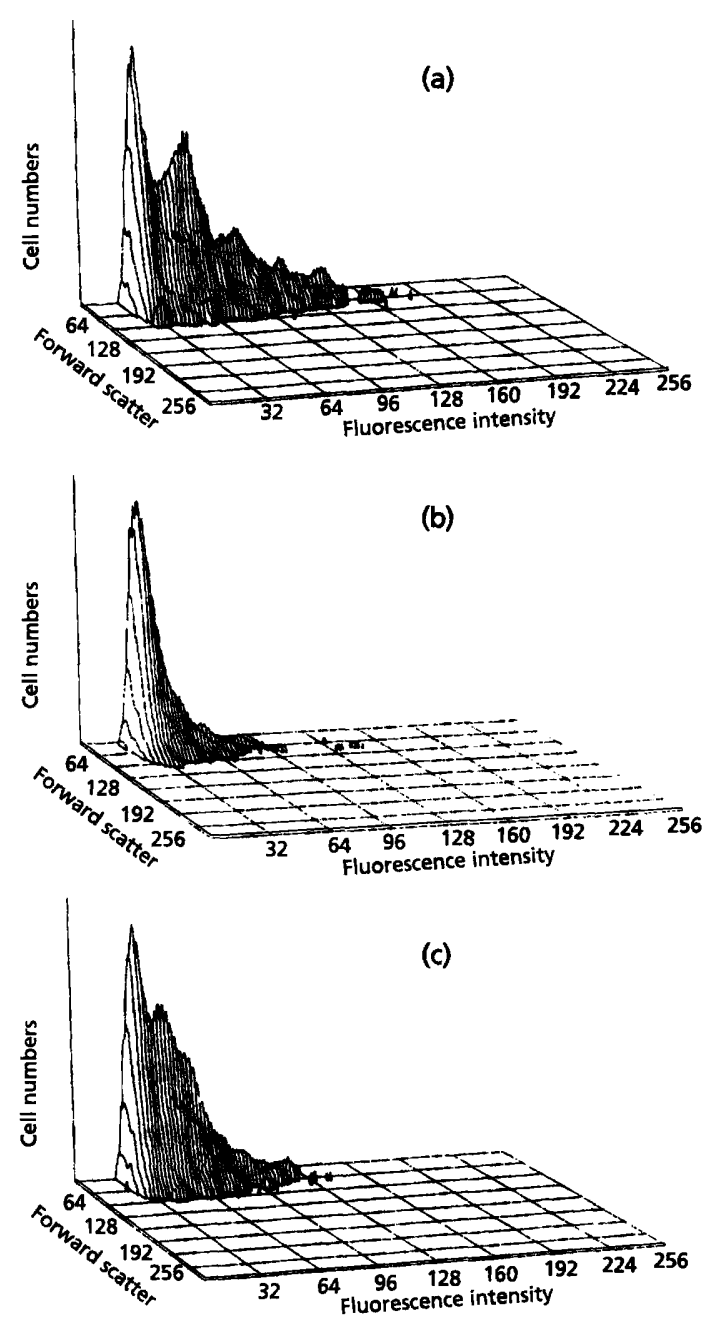

Fig. 5. Initiation of chromosome replication during recovery. Cells at various times during recovery were incubated with rifampicin for $30 \mathrm{~min}$. The cells were then stained with Hoechst 33342 and analysed by flow cytometry. Cells were treated with rifampicin (a) during exponential growth, (b) during starvation, (c) after $150 \mathrm{~min}$ recovery.

120-150 min. At lower cell densities no increase in cell numbers was observed after $380 \mathrm{~min}$. If starved cells were diluted back into the culture fluid from which they were harvested (supplemented with glucose and amino acids), recovery at all cell densities was observed, although the lag period at the lowest cell density was extended by about $30 \mathrm{~min}$ (Fig. 3b). The densitydependent recovery phenomenon was not observed when cells were resuspended in BHI (Fig. 3c).

\section{Macromolecular synthesis during recovery}

During long-term starvation, metabolism is reduced. Changes in the rate of RNA and protein synthesis during recovery were determined by the incorporation of $\left[{ }^{3} \mathrm{H}\right]$ uridine and $\left[{ }^{3} \mathrm{H}\right]$ methionine, respectively (Fig. 4). Starved cells, prior to recovery, demonstrated very low 

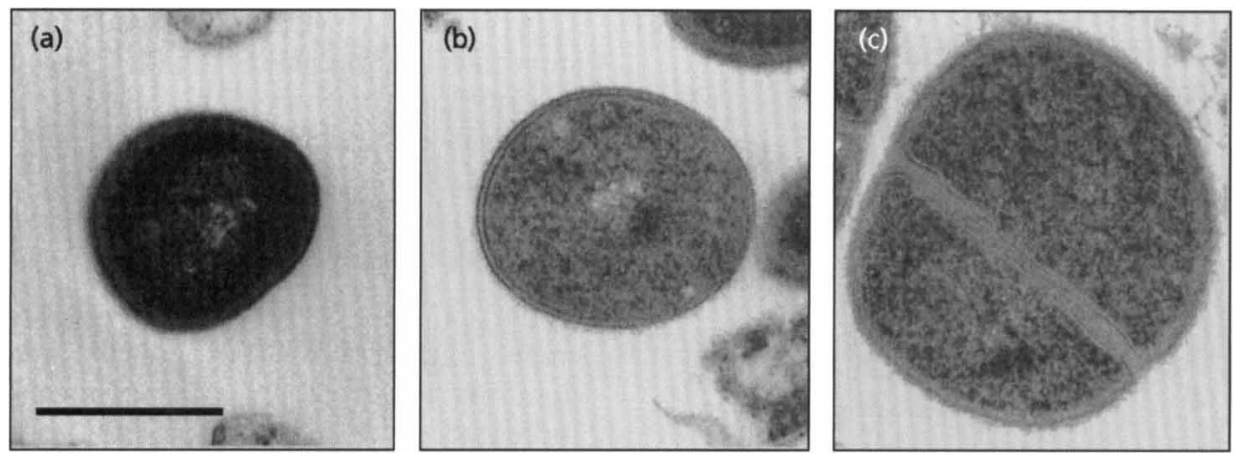

Fig. 6. Morphological changes during recovery of starved cells. Representative micrographs of (a) starved cells, (b) cells recovered for $30 \mathrm{~min}$, (c) cells recovered for $90 \mathrm{~min}$. Cells were stained with uranyl acetate and Reynolds lead citrate before microscopy. Bar, $0.5 \mu \mathrm{m}$.

rates of uridine incorporation $\left(1.6 \times 10^{-5}\right.$ d.p.m. $\min ^{-1}$ per c.f.u.). RNA synthesis was found to increase immediately upon the addition of nutrients. Compared to the starved cells, within the first 10 min of recovery the rate of uridine incorporation increased by about 100 fold, before slowing to around 20 -fold for the remaining recovery period $(10-60 \mathrm{~min})$. Incorporation of $\left[{ }^{3} \mathrm{H}\right]$ uridine was arrested in the presence of the RNA synthesis inhibitor rifampicin, confirming that $\left[{ }^{3} \mathrm{H}\right]$ uridine incorporation reflected the rate of RNA synthesis (Fig. 4a).

Protein synthesis during recovery was measured by the incorporation of $\left[{ }^{3} \mathrm{H}\right]$ methionine (Fig. 4b). Upon the addition of nutrients the rate of methionine incorporation increased 10 -fold after $10 \mathrm{~min}, 30$-fold by $20 \mathrm{~min}$ and was over 50 -fold greater after $30 \mathrm{~min}$ of recovery than the basal level during starvation survival $\left(1.2 \times 10^{-6}\right.$ d.p.m. $\min ^{-1}$ per c.f.u. $)$. Therefore, unlike RNA synthesis, there is a slight lag phase before protein synthesis increases. Interestingly, the addition of rifampicin to recovering cells did not completely abolish protein synthesis. Methionine incorporation could be detected up until $45 \mathrm{~min}$ into recovery although threefold less methionine was incorporated (Fig. 4b). During this time no RNA was synthesized in the presence of rifampicin, as shown by uridine incorporation (Fig. 4a); therefore the proteins produced must be translated from transcripts synthesized during starvation which are presumably very stable.

Methionine and uridine incorporation was also monitored after the addition of either glucose or amino acids alone to starved cells (data not shown). Neither nutrient resulted in an increased rate of protein or RNA synthesis.

\section{Initiation of chromosome replication during recovery}

Chromosome replication was analysed by flow cytometry during recovery. Cells at various stages during recovery were treated with rifampicin, which inhibits the initiation of DNA replication whilst allowing completion of any existing rounds of replication. The number of chromosomes in the cell was then determined by flow cytometry after staining DNA with the fluorescent DNA chelating dye Hoechst 33342. During the exponential phase of growth $\left(\mathrm{OD}_{600} 0.6\right.$; Fig. $\left.5 \mathrm{a}\right)$, multiple peaks of fluorescence were observed corresponding to cells undergoing several simultaneous rounds of chromosome replication. The peaks at fluorescence channel numbers 32 and 64 probably correspond to cells with one and two chromosomes. In comparison, cells which had been starved gave only a single peak of fluorescence (peak fluorescence channel number 32), indicating that no chromosome replication was occurring in the majority of cells and that starved cells most likely contain a single chromosome (Fig. 5 b). By 150 min of recovery, two major peaks of fluorescence were observed (Fig. 5c). These correspond to cells with one and two chromosomes after rifampicin treatment (channel numbers 32 and 64), indicating the initiation of a single round of chromosome replication. Chromosome replication could first be detected after $90 \mathrm{~min}$ recovery (data not shown).

\section{Morphological changes during recovery}

Upon starvation, the morphology of $S$. aureus alters, with cells becoming smaller and the cytoplasm staining more electron densely (Fig. 6a ; Watson et al., 1998). To resume vegetative growth, the starved cell must increase in size until it reaches twice the minimal cell volume, at which time the cell will divide (Donachie \& Robinson, 1987). The morphology of cells during recovery was monitored by electron microscopy to establish the timing of morphological changes. Within $30 \mathrm{~min}$ of recovery the diameter of the cell had typically increased approximately $1 \cdot 5$-fold and the electron-dense appearance of the cytoplasm was lost (Fig. 6b). By $90 \mathrm{~min}$ of recovery the number of cells with partial or complete division septa increased from $20 \%$ during starvation to $40 \%$ (Fig. 6c).

\section{Analysis of recovery-associated protein synthesis}

Studies on protein synthesis during long-term starvation of $S$. aureus have revealed the production of several starvation-specific proteins (Watson et al., 1998). 

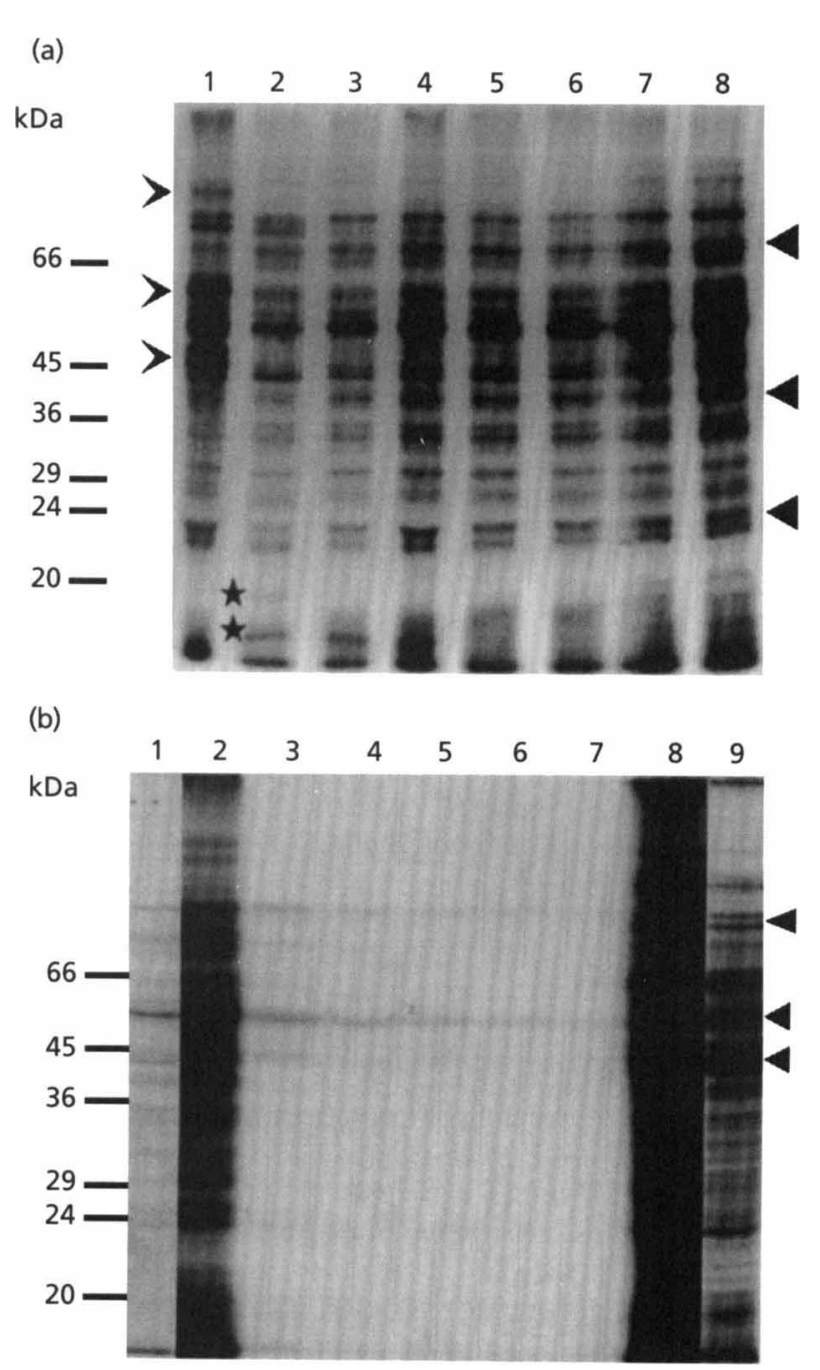

Fig. 7. Changes in protein profiles during recovery of $S$. aureus 8325-4. (a) Cells were pulse-labelled with [ ${ }^{35}$ S]methionine during recovery and cell lysate containing $2 \times 10^{4} \mathrm{~d} . \mathrm{p} . \mathrm{m}$. loaded in each lane. Lanes: $1,7 \mathrm{~d}$ starved cells labelled for $24 \mathrm{~h} ; 2$, pulse-labelling at 0-30 min during recovery; lanes 3, 30-45 min; 4, 45-60 min; 5, 60-75 min; 6, 75-90 min; 7, 105-120 min; 8, 135-150 min. >, Starvation-specific proteins; 4 , starvation and recovery proteins; $\star$, recovery-specific proteins. (b) Identification of proteins synthesized from long-lived transcripts. Cells were treated with rifampicin $\left(330 \mu \mathrm{g} \mathrm{ml}^{-1}\right)$ for $0,5,10,15,30$ min (lanes $3-7$, respectively), prior to recovery in the presence of $\left[{ }^{35} \mathrm{~S}\right]$ methionine for $30 \mathrm{~min}$. Proteins synthesized during $30 \mathrm{~min}$ recovery in the absence of rifampicin, and in starved cells labelled for $24 \mathrm{~h}$, are shown in lanes 2 and 8 , respectively. Shorter exposure times of lanes 2 and 8 are shown in lanes 1 and 9 , respectively, to enable better resolution of the bands due to the high incorporation of the label in these samples. Total cell protein from $2 \times 10^{5}$ c.f.u. $\mathrm{ml}^{-1}$ was loaded in each lane. The positions of starvation-recovery proteins are indicated (4). Molecular mass markers are indicated in $\mathrm{kDa}$.

Proteins synthesized during the recovery period were analysed to determine if any recovery-specific proteins were produced. Cells were pulse-labelled with $\left[{ }^{35} S\right]$ methionine during recovery, followed by the separation of the proteins by SDS-PAGE and fluorography.
Due to the low rate of methionine incorporation by the starved cell population, the cells had to be labelled with $\left.{ }^{35} \mathrm{~S}\right]$ methionine for $24 \mathrm{~h}$. Since the rate of protein synthesis increased rapidly during recovery (Fig. 6b), proteins could be visualized after 30 min pulse-labelling at the initiation of recovery and thereafter only a $15 \mathrm{~min}$ pulse-labelling was required.

Many changes in protein expression occurred during starvation recovery (Fig. 7a). Representative proteins demonstrating some of the changes that occurred are indicated. One of the most striking changes was the disappearance of several predominant starvation proteins within the first $30 \mathrm{~min}$ of recovery (approx. molecular mass $150 \mathrm{kDa}, 61.5 \mathrm{kDa}$ and $45 \mathrm{kDa}$; Fig $7 \mathrm{a}$, lane 1 versus lane 2). Several proteins (e.g. those of approx. molecular mass 97.5 and $23 \mathrm{kDa}$ ) were expressed both during starvation and throughout recovery (Fig $7 \mathrm{a}$, lanes $1-8$ ). Some proteins, including one of $39 \mathrm{kDa}$, appeared during the first $30-60 \mathrm{~min}$ of recovery and were present throughout the remaining recovery period. Interestingly, two small proteins, of 20 and $17.7 \mathrm{kDa}$, appeared only transiently during the first $30 \mathrm{~min}$ and $0-60 \mathrm{~min}$ of recovery, respectively. These proteins appear to be possibly recovery-specific, demonstrating that there is a temporal order in expression of proteins during recovery.

\section{Evidence for the presence of long-lived mRNA transcripts in starved cells}

Methionine incorporation studies in the presence of the RNA synthesis inhibitor rifampicin suggested that protein synthesis could occur during recovery without de novo RNA synthesis. To determine if proteins were translated from long-lived mRNA transcripts synthesized during starvation, cells were treated with rifampicin at intervals prior to the initiation of recovery in the presence of $\left.{ }^{35} \mathrm{~S}\right]$ methionine. Analysis of labelled proteins by SDS-PAGE and visualization of proteins by fluorography (Fig. $7 \mathrm{~b}$ ) revealed that several proteins continued to be synthesized in rifampicin-treated cells during recovery. Since only a few proteins were synthesized, this suggests that only specific transcripts have a long half life. Two of the proteins, of approximate molecular mass $100 \mathrm{kDa}$ and $52 \mathrm{kDa}$, were still synthesized in cells pre-treated with rifampicin for $30 \mathrm{~min}$ (Fig 7b, lane 7), suggesting that these transcripts are extremely long-lived. Three of the proteins (approx. molecular mass $100 \mathrm{kDa}, 52 \mathrm{kDa}$ and $45 \mathrm{kDa}$ ) were identified as probably being expressed in both starved and recovering cells.

\section{DISCUSSION}

The human pathogen $S$. aureus is able to inhabit a wide range of niches and to persist for long periods under conditions of nutrient limitation. To survive such wide fluctuations in nutrient availability, $S$. aureus, like many non-spore-forming bacteria, has developed a starvationsurvival mechanism. Starved bacteria are able to respond 
rapidly to the availability of nutrients and recover to form a new vegetative cell.

Recovery, leading to the establishment of growth and cell division, could be initiated by the addition of nutrients to the starved cell population. Both the addition of a complex medium (BHI) or a defined mixture of glucose and amino acids could induce recovery. Interestingly, the addition of either glucose or amino acids alone could not induce recovery of starved cells or alter the rate of RNA or protein synthesis. This suggests that the starved cell is able to sense the environment and respond only when sufficient nutrients for growth are available. The lack of growth upon the addition of glucose to long-term starved cultures also shows that during long-term starvation excess amino acids may well be metabolized. The recovery of Vibrio sp. S14 can be induced by the addition of glucose alone, although this has a longer lag period than that observed with the addition of a mixture of amino acids and glucose (Albertson et al., 1990b). The glucose-associated lag period was due to the induction of the stringent response as a result of amino acid limitation. During this period, amino acid biosynthetic pathways are induced, enabling the de novo synthesis of amino acids.

Recovery of starvation-induced dormant cells of $M$. luteus has been shown to require the addition of a 'recovery pheromone' to break dormancy and restore growth in the presence of nutrients (Votyakova et al., 1994). This pheromone is secreted by growing cells and dormancy can be broken by addition of growing cells or their conditioned culture fluid to dormant cells. Interestingly, a factor (or factors) also appears to be required for the recovery of starved $S$. aureus cells. When starved cells were resuspended in fresh CDM at low cell densities they failed to grow, but did grow in their spent culture fluid supplemented with CDM nutrients. A factor (or factors) is produced by the cells and is present in the spent culture fluid which is required for recovery from starvation at low cell densities. Unlike the $M$. luteus pheromone, this factor is likely to be a nutrient, since recovery at low cell densities can be induced by resuspension in BHI.

During recovery there was a lag period of about 120-150 min before the first round of cell division. During this lag period the cell is presumably reversing the processes required for the formation and maintenance of the starvation-survival state. Unlike Vibrio $\mathrm{sp}$. S14, the duration of this lag period did not increase with the age of the culture (Albertson et al., 1990b). It was proposed that the age-dependent lag period exhibited by Vibrio sp. was due to the increasing time taken for cells to prepare for chromosome replication as the result of the gradual shut down of the biosynthetic machinery over time. Presumably therefore the degradation of the biosynthetic pathways in $S$. aureus is completed within two days, resulting in a constant lag period during which these pathways are re-established.

The timing of events during the lag period before the first round of cell division was determined, as
Time (min)

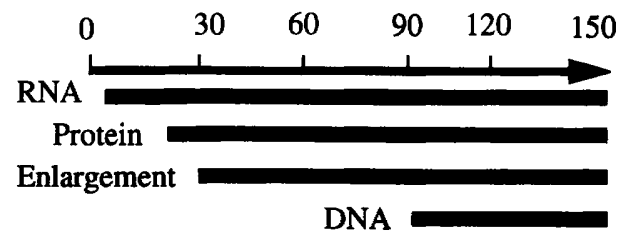

Cell Division

Fig. 8. Timing of events during the starvation recovery of S. aureus.

summarized in Fig. 8. Immediately upon the addition of nutrients to the starved cell a detectable increase in the rate of RNA synthesis was observed, demonstrating that the RNA biosynthetic machinery is primed to rapidly make large quantities of RNA during recovery. A lag period of about $5 \mathrm{~min}$ was observed before a significant increase in protein synthesis could be detected. This lag period is presumably due to the time taken to reestablish the protein synthetic pathways. In contrast, Vibrio sp. S14 can resume rapid protein synthesis immediately upon nutritional upshift, which is attributed to the excess of ribosomes over the apparent need for translation during starvation (Flärdh et al., 1992). This excess of ribosomes enables starved cells to rapidly resume protein synthesis upon recovery, without the need to synthesize new ribosomes.

During recovery cells enlarge within $30 \mathrm{~min}$ to a size comparable to typically growing cells. At the same time the cytoplasm loses its electron-dense appearance. It is unknown what events occur during this period, but rapid peptidoglycan synthesis must be involved to enable the cell wall to compensate for the swelling cytoplasm. Chromosome replication was initiated after about $90 \mathrm{~min}$ into recovery, with the first cell division occurring approximately $60 \mathrm{~min}$ later. This is similar to what was observed for Vibrio sp. S14, where cell division also occurred $60 \mathrm{~min}$ after an increase in DNA replication (Albertson et al., 1990b).

The profile of proteins expressed during starvation changed during the transition from starvation through recovery, as shown by pulse-labelling and SDS-PAGE studies. Within $30 \mathrm{~min}$ several predominant starvationassociated proteins were down-regulated. These proteins are presumably responsible for the increased survival and resistance properties of starved cell, as well as proteins involved in nutrient scavenging. The apparent down-regulation could also be explained by continued low-level synthesis, which could not be detected over the period of pulse-labelling during recovery. Other proteins synthesized during starvation are also synthesized during recovery, and therefore may be involved in important house-keeping roles in the cell. Interestingly, two proteins were identified which appear transiently during the early stages of recovery. Similar changes in protein synthesis have also been noted during 
recovery of E. coli, P. putida and Vibrio sp. S14 (Albertson et al., 1990b ; Givskov et al., 1994b; Marouga \& Kjelleberg, 1996; Siegele \& Guynn, 1996). Characterization of the recovery-specific proteins will allow their roles in the process to be established and may lead to a greater understanding of the mechanisms involved in the recovery response.

The synthesis of several proteins during recovery was found not to be dependent on de novo RNA synthesis and therefore these proteins must be translated from long-lived mRNA transcripts present in the starved cell. Similar transcripts have been observed during starvation and recovery of Vibrio sp. S14, with several of these transcripts only translated immediately upon recovery, and therefore silent during starvation (Albertson et al., 1990b; Marouga \& Kjelleberg, 1996). A contributing factor to the stabilization of these transcripts could be complex secondary structures at their $3^{\prime}$ end, which can protect mRNA from $3^{\prime}-5^{\prime}$ exonuclease degradation (Higgins et al., 1993). Recovery proteins translated from starvation-associated transcripts may provide a mechanism for the cell to rapidly respond to changes in environmental conditions, allowing recovery and exploitation of increased nutrient availability. Identification and characterization of the long-lived transcripts will allow their importance to be established and their apparent stability assessed.

The similarity between the starvation-survival and recovery responses of $S$. aureus, $P$. putida, E. coli and Vibrio sp. S14 suggests that common mechanisms have evolved to enable persistence in unstable conditions, cell spread and the colonization of new environments (Albertson et al., 1990b; Givskov et al., 1994a ; Siegele \& Guynn, 1996; Watson et al., 1998). Although many recovery-specific proteins have been identified by twodimensional gel analysis in Vibrio sp. S14, E. coli and $P$. putida, the function of these proteins remains unknown. Other approaches have identified components involved in recovery in $E$. coli, including the $\operatorname{rel} A, \operatorname{relB}$, fis and surB gene products (Ball et al., 1992; Fiil \& Friesen, 1968; Mosteller, 1978; Siegele \& Kolter, 1993). Mutations in relA and relB, which encode components of the stringent response, lead to defective recovery in $E$. coli and similar effects in Vibrio sp. S14 (Fiil \& Friesen, 1968; Flärdh et al., 1992; Mosteller, 1978). Mutations in fis, a DNA-binding protein which participates in transcription and DNA replication, have been shown to affect recovery, resulting in an increased lag period before regrowth during nutrition upshift (Ball et al., 1992). A mutation in surB of $E$. coli, which is involved in cytochrome oxidase biosynthesis, gave rise to a temperature-sensitive mutant which was unable to recover from starvation (Siegele \& Kolter, 1993). Recently, transposon insertion mutants of Sinorhizobium meliloti, which remain viable during starvation but are unable to recover from starvation and resume growth, have been isolated. This has led to the identification of a locus encoding a possible $\mathrm{ABC}$ transporter and a gene potentially involved in amino acid biosynthesis, both of which are required during recovery (Uhde et al., 1997).
We are currently isolating and characterizing $S$. aureus mutants defective in recovery from starvation. This will allow components involved in the response to be identified and the molecular recovery mechanism to be elucidated.

\section{ACKNOWLEDGEMENTS}

This work was supported by the Royal Society (S. J.F.) and the BBSRC/Celsis connect programme (M.O.C). We would like to thank Ian Morton for his technical assistance with the flow cytometry.

\section{REFERENCES}

Åkerlund, T., Nordström, K. \& Bernander, R. (1995). Analysis of cell size and DNA content in exponentially growing and stationary phase batch cultures of Escherichia coli. J Bacteriol $177,6791-6797$.

Albertson, N. H., Nystrom, T. \& Kjelleberg, S. (1990a). Functional mRNA half-lives in the marine Vibrio sp. S14 during starvation and recovery. J Gen Microbiol 136, 2195-2199.

Albertson, N. H., Nystrom, T. \& Kjelleberg, S. (1990b). Macromolecular synthesis during recovery of the marine Vibrio sp. S14 from starvation. J Gen Microbiol 136, 2201-2207.

Aldea, M., Hernandezchico, C., Delacampa, A. G., Kushner, S. R. \& Vicente, M. (1988). Identification, cloning and expression of $b o l A$, an $f t s Z$ dependent morphogene of Escherichia coli. J Bacteriol 170, 5169-5176.

Ball, C. A., Osuna, R., Ferguson, K. C. \& Johnson, R. C. (1992). Dramatic changes in Fis levels upon nutrient upshift in Escherichia coli. J Bacteriol 174, 8043-8056.

Diaper, J. P. \& Edwards, C. (1994). Survival of Staphylococcus aureus in lakewater monitored by flow-cytometry. Microbiology $140,35-42$.

Donachie, W. D. \& Robinson, A. C. (1987). Cell division: parameter values and the process. In Escherichia coli and Salmonella typhimurium: Cellular and Molecular Biology, vol. 2, pp. 1578-1593. Edited by F. C. Neidhardt and others. Washington, DC: American Society for Microbiology.

Fiil, N. \& Friesen, J. D. (1968). Isolation of relaxed mutants of Escherichia coli. J Bacteriol 175, 53-63.

Flärdh, K., Cohen, P. S. \& Kjelleberg, S. (1992). Ribosomes exist in large excess over the apparent demand for protein synthesis during carbon starvation in marine Vibrio sp. Strain CCUG 15956. J Bacteriol 174, 6780-6788.

Givskov, M., Eberl, L., Moller, S., Poulsen, L. K. \& Molin, S. (1994a). Responses to nutrient starvation in Pseudomonas putida KT2442: analysis of general cross protection, cell shape and macromolecular content. J Bacteriol 176, 7-14.

Givskov, M., Eberl., L. \& Molin, S. (1994b). Responses to nutrient starvation in Pseudomonas putida KT2442: two-dimensional electrophoretic analysis of starvation- and stress-induced proteins. J Bacteriol 176, 4816-4824.

Hengge-Aronis, R. (1996). Regulation of gene expression during entry into stationary phase. In Escherichia coli and Salmonella: Cellular and Molecular Biology, pp. 1497-1512. Edited by F. C. Neidhardt and others. Washington, DC: American Society for Microbiology.

Higgins, C. F., Causton, H. C., Dance, G. S. C. \& Mudd, E. A. (1993). The role of $3^{\prime}$-end in mRNA stability and decay. In Control of Messenger RNA Stability, pp. 13-30. Edited by J. Belasco \& G. Brawerman. San Diego, CA: Academic Press. 
Hussain, M., Hastings, J. G. M. \& White, P. J. (1991). A chemically defined medium for slime production by coagulase-negative staphylococci. J Med Microbiol 34, 143-147.

Kaprelyants, A. S., Mukamolova, G. V. \& Kell, D. B. (1994). Estimation of dormant Micrococcus luteus cells by penicillin lysis and by resuscitation in cell-free spent culture medium at high dilution. FEMS Microbiol Lett 115, 347-352.

Kjelleberg, S., Albertson, N., Flardh, K., Holmquist, L., Jouperjaan, A., Marouga, R., Ostling, J., Svenblad, B. \& Weichart, D. (1993). How do non-differentiating bacteria adapt to starvation? Antonie Leeuwenhoek 63, 331-341.

Kloos, W. E. \& Bannerman, T. L. (1994). Update on clinical significance of coagulase-negative staphylococci. Clin Microbiol Rev 7, 117-140.

Kolter, R., Siegele, D. A. \& Tormo, A. (1993). The stationary-phase of the bacterial life-cycle. Annu Rev Microbiol 47, 855-874.

Marouga, R. \& Kjelleberg, S. (1996). Synthesis of immediate upshift (Iup) proteins during recovery of marine Vibrio sp. strain S14 subjected to long-term carbon starvation. J Bacteriol 178, 817-822.

Mosteller, R. D. (1978). Evidence that glucose starvation-sensitive mutants are altered in relB locus. J Bacteriol 133, 1034-1037.

Mukamolova, G. V., Yanopolskaya, N. D., Votyakova, T. V., Popov, V. I., Kaprelyants, A. S. \& Kell, D. B. (1995). Biochemical changes accompanying the long-term starvation of Micrococcus luteus cells in spent growth-medium. Arch Microbiol 163, 373-379.

Mulvey, M. R., Switala, J., Borys, A. \& Loewen, P. C. (1990). Regulation of transcription of katE and katF in Escherichia coli. $J$ Bacteriol 172, 6713-6720.

Novick, R. P. (1967). Properties of a high-frequency transducing phage in Staphylococcus aureus. Virology 33, 155-156.

Nystrom, T., Olsson, R. M. \& Kjelleberg, S. (1991). Survival, stress resistance, and alteration in protein expression in the marine Vibrio sp. strain S14 during starvation for different individual nutrients. Appl Environ Microbiol 58, 55-65.
Oliver, J. D. (1993). Formation of viable but non-culturable cells. In Starvation in Bacteria, pp. 239-268. Edited by S. Kjelleberg. New York: Plenum.

Siegele, D. A. \& Guynn, L. J. (1996). Escherichia coli proteins synthesized during recovery from starvation. J Bacteriol 178, 6352-6356.

Siegele, D. A. \& Kolter, R. (1993). Isolation and characterisation of an Escherichia coli mutant defective in resuming growth after starvation. Genes Dev 7, 2629-2640.

Spector, M. P. \& Cubitt, C. L. (1992). Starvation-inducible loci of Salmonella typhimurium - regulation and roles in starvationsurvival. Mol Microbiol 6, 1467-1476.

Spector, M. P., Aliabadi, Z., Gonzalez, T. \& Foster, J. W. (1986). Global control in Salmonella typhimurium-two-dimensional electrophoretic analysis of starvation-inducible, anaerobiosisinducible, and heat shock-inducible proteins. J Bacteriol 168, $420-424$.

Uhde, C., Schmidt, R., Jording, D., Selbitschka, W. \& Pahler, A. (1997). Stationary-phase mutants of Sinorbizobium meliloti are impaired in stationary-phase survival or in recovery to logarithmic growth. J Bacteriol 179, 6432-6440.

Votyakova, T. V., Kaprelyants, A. S. \& Kell, D. B. (1994). Influence of viable cells on the resuscitation of dormant cells in Micrococcus luteus cultures held in an extended stationary phase: the population effect. Appl Environ Microbiol 60, 3284-3291.

Watson, S. P., Clements, M. O. \& Foster, S. J. (1998). Characterisation of the starvation-survival response of Staphylococcus aureus. J Bacteriol 180, 1750-1758.

Xu, H. S., Roberts, N., Singleton, F. L., Attwell, R. W., Grimes, D. J. \& Colwell, R. R. (1982). Survival and viability of nonculturable Escherichia coli and Vibrio cholerae in the estuarine and marine environment. Microb Ecol 8, 313-323.

Received 19 January 1998; revised 6 March 1998; accepted 11 March 1998. 